\title{
PERUMUSAN VISI OGANISASI IKATAN PELAJAR NAHDLATUL ULAMA (IPNU) TAHUN 1954
}

\author{
Wahanani Mawasti \& Emha Nurul Adli \\ STID Al-Hadid, Surabaya \\ wahananimawasti79@gmail.com \&Adliemha20@gmail.c0m
}

\begin{abstract}
Abstrak: Organisasi dakwah merupakan organisasi nirlaba yang karakter karyawan/anggotanya banyak berorientasi pada nilai, cita-cita (ajaran) dan pengabdian. Adanya visi menjadi pengikat hubungan organisasi dakwah dengan anggota/karyawannya. Meskipun visi merupakan hal yang penting dalam eksistensi organisasi, namun tak jarang visi dalam organisasi nirlaba dirumuskan hanya bersifat formalistik tanpa perumusan visi yang baik. Tulisan ini mendeskripsikan perumusan visi organisasi dakwah IPNU 1954. Organisasi IPNU memiliki visi yang masih dipertahankan sejak 1954 hingga sekarang (2018) sebagai khitah organisasi. Visi tersebut dirumuskan dengan proses serta pertimbangan yang matang, sehingga memungkinkan dikaji sebagai pelajaran bagi organisasi dakwah lainnya. Teori yang digunakan milik Susanto dan Kuncoro sedangkan metode penelitiannya deskriptif kualitatif. Kesimpulan yang didapatkan, yaitu perumusan visi IPNU dilakukan melalui tahapan: (1) perumusan masalah yang melatarbelakangi visi, (2) perumusan gagasan cita-cita organisasi sebagai jawaban atas persoalan yang menggelisahkan pendiri, (3) konsolidasi gagasan visi, (4) pembentukan organisasi Untuk dapat memformalkan visi organisasi, (5) peresmian visi organisasi IPNU oleh struktur yang berwenang dalam organisasi, (6) perumusan redaksi visi. Perumusan visi organisasi IPNU mempertimbangkan: nilai-nilai pendiri organisasi IPNU, persoalan yang ada di masyarakat Islam pada tahun 1954, kondisi organisasi Islam lainnya (HMI\&PII), serta kondisi organisasi induknya (organisasi NU).
\end{abstract}

Kata kunci: perumusan visi, visi organisasi, organisasi dakwah, IPNU.

Abstract: Da'wah organization is a non-profit one whose employees/members' characters orientate towards values, aspiration (teachings) and dedication. The existence of a vision becomes a relationship tightener between da'wah organization and its employees/members. Even though a vision is an essential matter in organizational existence, it is often that a vision of a non-profit organization is formulated in a mere formality - without a good vision formulation. The paper describes on formulating da'wah organization's vision of IPNU 1954. IPNU has a vision which remain to be perpetuated since 1954 until now (2018) as the first principle of organization. This vision was formulated with a mature process and considerations. Therefore, it is possible to be studied for other da'wah organizations. The theory applied for this study belongs to Susanto and Kuncoro while its research method is qualitative descriptive. It is concluded that the formulating vision of IPNU was conducted through phases: (1) formulating problem which underlay the vision, (2) formulating the idea of organizational aspiration as the solution of problem perturbing the founder, (3) consolidating the idea of vision, (4) forming an organization in order to be able to make the organizational vision formal, (5) inaugurating IPNU's organizational vision by the authoritative structure in the organization, (6) formulating the text of vision. The process of formulating IPNU's vision considers: values of the founder of IPNU, problems available in Islamic society in 1954, condition of other Islamic organization (HMI\&PII), and condition of the main organization, NU.

Key words: formulating a vision, organizational vision, da'wah organization, IPNU. 


\section{Pendahuluan}

Visi merupakan tujuan organisasi, filosofis/alasan keberadaan suatu lembaga atau organisasi, dan mengungkapkan ke mana organisasi itu akan berkembang. Dengan adanya visi, para stakeholder akan memiliki langkah terpadu mencapai tujuan. ${ }^{1}$ Visi berhubungan dengan gambaran citacita yang ingin diwujudkan oleh organisasi. Tanpa adanya visi maka sebuah organisasi tidak akan terbentuk dan eksis dalam jangka waktu yang lama. Perumusan visi adalah salah satu hal yang penting bagi perkembangan organisasi kedepan, karena visi dapat memberikan arah yang jelas ke mana organisasi ke depannya. ${ }^{2}$ Pernyataan visi memberikan gambaran masa depan yang ingin dicapai organisasi secara keseluruhan. Visi merupakan tujuan organisasi dengan hierarki tertinggi yang dibangun dari visi individu, kelompok, dan organisasi. ${ }^{3}$ Perlunya visi tidak dibatasi dalam domain pengabdiannya. Bukan hanya organisasi profit yang memerlukan visi, organisasi nonprofit (nirlaba) pun memerlukan sebuah visi organisasi. ${ }^{4}$ Organisasi seperti perguruan tinggi, rumah sakit, yayasan, perkumpulan sering berbentuk organisasi nirlaba. Organisasi nirlaba adalah organisasi nonprofit yang bertujuan memaksimalkan pelayanan dan tidak mengenal pemegang saham. ${ }^{5}$

\footnotetext{
1 Yusuf Hamdan, "Pernyataan Visi Dan Misi Dalam Perguruan Tinggi," Mimbar Volume XVII, No. 1 (Januari-Maret 2001): 101-102.

2 Wawan Wongso, "Perumusan Visi, Misi, Value Statement Serta Standarisasi Proses Bisnis Pada Perusahan Berbasis Bisnis Keluarga," Calyptra: Jurnal IImiah Mahasiswa Universitas Surabaya Vol.3 No.1, (2014): 3.
}

Organisasi dakwah termasuk kategori organisasi nirlaba. Organisasi dakwah, tentu saja tujuan organisasinya terkait dengan mengemban misi dakwah bukan dalam rangka menghasilkan keuntungan bagi pemegang saham. Tujuan organisasi dakwah dapat diformulasikan sebagai upaya mengaktualisasikan nilai-nilai ajaran Islam dalam bentuk amar makruf nahi mungkar dan amal saleh dalam kehidupan sehari-hari, baik secara pribadi, keluarga, bermasyarakat, dan bernegara sehingga dapat mewujudkan masyarakat thayyibah yang sejahtera lahir dan batin serta berbahagia dunia dan akhirat. ${ }^{6}$ Dalam konteks organisasi dakwah, visi juga merupakan aspek penting dalam sebuah perencanaan strategis organisasi dakwah. Pentingnya visi dapat terlihat dari sejarah dakwah pada masa Rasulullah. Shofyan Affandy menjelaskan bahwa Rasulullah sejak dini telah memiliki visi jangka panjang yang jelas, sehingga setiap langkah yang dilakukan telah terencana dan memiliki hubungan logis dengan langkah-langkah di masa setelahnya. Visi jangka panjang Rasulullah telah dimulai sejak dakwah di Aqabah, kemudian ditindaklanjuti dengan mengirimkan juru dakwah ke Yatsrib. $^{7}$ Mengingat pentingnya visi dalam organisasi dakwah, maka sebuah organisasi dakwah perlu memiliki visi. Visi perlu diformulasikan dengan baik agar dapat secara efektif

\footnotetext{
3 Soemengen Sutomo, "Manajemen Strategis Organisasi Nirlaba," Jurnal Kesehatan Masyarakat Nasional Vol.1, No.4, (2007): 179.

${ }^{4}$ Hamdan, "Pernyataan Visi." 102.

${ }^{5}$ Sutomo, "Manajemen Strategis.," 177.

6 Shofyan Affandy, Dakwah Strategik: Sebuah Ancangan Teoritis \& Filosofis, (Surabaya : Avvaterra, 2017), 26.

7 Ibid., 43-44.
} 
memengaruhi kinerja organisasi di masa depan.

Menurut Senge, P.M. (1990) efektivitas visi organisasi sebagian berhubungan dengan sifat pemicu (situasi pendorong) penciptaan visinya. Visi dapat dirumuskan sebagai reaksi sederhana/tanggapan terhadap kekuatan institusional lingkungan eksternal yang menuntut penciptaan pernyataan visi, untuk dianggap sebagai organisasi yang sah di bidang tertentu. Meskipun kekuatan institusional bisa memaksa penciptaan visi, namun dapat mengarah pada terciptanya visi negatif, bukan positif. Visi negatif cenderung mendukung status quo, sedangkan visi positif mengarah ke perubahan nyata. Visi positif yang inspiratif, diresapi dengan nilai-nilai, dan transparant dalam pendekatannya untuk mencapai masa depan yang lebih baik. Sedangkan, visi negatif adalah visi yang kurang daya tarik emosional dan kredibilitas untuk memacu perubahan. Visi yang negatif seperti sebuah mitos yang diritualkan. ${ }^{8}$

Dalam organisasi dakwah visi seharusnya dirumuskan dengan baik agar menjadi visi yang bernilai positif. Namun, tak jarang visi dalam sebuah organisasi berkarakteristik nirlaba dijumpai visi yang lahir hanya karena tuntutan lingkungan eksternal dan bersifat formalistik semata. Sebagaimana pandangan O'Connell terkait dengan visi dalam lembaga-lembaga nonprofit bahwa visi yang dirumuskan dari dorongan untuk

8 O'Connell, et al, "Organizational Visioning: An Integrative Review," Group \& Organization Management, Vol. 36(1), (2011): 107.

${ }^{9}$ Ibid.

${ }^{10}$ Pengamatan pada visi beberapa organisasi dakwah dalam beberapa sumber berikut: http://www.remasdarussalammudiharjo.com/p/visi -misi.html,

http://lisanovrianti.blogspot.co.id/2012/11/visi- penyesuaian institusional eksternal sering termanifestasi dalam lembaga-lembaga nonprofit (nirlaba), ketika para pemimpin organisasi nirlaba dituntut untuk membuat visi formal agar mendapatkan pendanaan dari lembaga di luar organisasi atau mendapat pengakuan dari lembaga akreditasi eksternal. Visi yang hanya berangkat dari tuntutan kekuatan eksternal seperti itu biasanya tidak mengarah pada perubahan yang nyata dan tidak efektif memengaruhi kinerja organisasi. ${ }^{9}$

Dalam realitasnya, dijumpai persoalan perumusan visi dalam organisasi dakwah. Beberapa organisasi dakwah memiliki visi sama persis dengan organisasi dakwah lainnya padahal berbeda organisasi dan lokasi organisasi. ${ }^{10} \mathrm{Hal}$ ini, mengesankan bahwa antara organisasi yang satu dengan yang lain tidak memiliki perbedaan visi, padahal seharusnya masing-masing organisasi merumuskan visi berdasarkan kondisi yang melingkupi lahirnya organisasi, sehingga memiliki perbedaan dan keunggulan kompetitif satu sama lainnya dan dapat memotivasi anggota organisasi. Yusuf Hamdan dalam penelitiannya juga menunjukan bahwa dalam praktiknya tidak semua organisasi nonprofit memiliki visi mengenai masa depan yang ingin dicapainya. Organisasi yang telah memiliki visi pun tidak semua merumuskannya secara tertulis dan sungguh-sungguh. Berbagai masalah yang dihadapi dalam membuat dan merumuskan visi secara

dan-misi-remaja-islam-masjid-akbar.html, http://remajamasjidtaqwa.blogspot.co.id/2014/06/ visi-dan-misi.html, http://remaja-masjid-jami-annurkarawang.blogspot.co.id/2015/, https://remasdomas.wordpress.com/visi-dan-misi/, http://forum-rmat.blogspot.co.id/2015/03/visimisi-dan-motto.html. 
tertulis ini melanda berbagai organisasi. Misalnya pada lembaga pendidikan tinggi sebagai salah satu bentuk organisasi nirlaba juga tidak jarang yang dijumpai tidak memiliki visi. ${ }^{11}$

Tulisan ini, bermaksud mendeskripsikan bagaimana perumusan visi organisasi, khususnya dalam konteks organisasi nonprofit yang berbentuk organisasi dakwah. Fokus penelitian ini pada aspek pertimbangan dan langkah-langkah dan pertimbangan yang dilaksanakan oleh organisasi IPNU dalam merumuskan sebuah visi pada tahun 1954., yaitu: "Terwujudnya pelajar-pelajar bangsa yang bertaqwa kepada Allah SWT, berakhlakul karimah, menguasai ilmu pengetahuan dan teknologi, memiliki kesadaran dan tanggung jawab terhadap terwujudnya tatanan masyarakat yang berkeadilan dan demokratis atas dasar ajaran Islam Ahlussunah Wal Jamaah."

Ada beberapa pertimbangan memfokuskan kajian pada perumusan visi IPNU tahun 1954 antara lain: pertama, IPNU merupakan organisasi pelajar yang cukup tua dan survive sejak 1954 hingga tahun 2018 di Indonesia. Keberhasilan IPNU yang bertahan hingga saat ini tidak dapat dilepaskan dari adanya visi IPNU. Hal itu ditunjukan oleh data sejarah bahwa pada saat awal berdiri, pengurus IPNU melakukan sosialisasi dan konsolidasi visi ke para remaja dari satu kota ke kota lain agar menarik minat remaja NU (spesifik menyasar pelajar NU yang bersekolah formal di maarif maupun pesantren) mau

\footnotetext{
11 Hamdan, "Pernyataan Visi.," 91.

12 Caswiyono Rusydie Cakrawangsa dkk., K.H. Moh. Tolchah Mansoer Biografi Profesor NU yang Terlupakan, (Lkis, 2009), 67.
}

bergabung ke IPNU. Hal ini kemudian, menarik para remaja NU untuk bergabung dengan IPNU, padahal sebelumnya remaja IPNU lebih banyak tertarik mengikuti organisasi kepemudaan yang bukan NU (seperti Himpunan Mahasiswa Islam [HMI] atau Pelajar Islam Indonesia [PII]). Namun, dengan adanya visi IPNU yang salah satunya menegaskan nilai organisasi ahlussunnah wal jam'ah maka otomatis pelajar-pelajar NU memilih untuk bergabung dengan IPNU. ${ }^{12}$ Keberhasilan konsolidasi visi ini ditunjukan dengan capaian dalam dua tahun berdiri berhasil membentuk seratus cabang yang tersebar di Indonesia. ${ }^{13}$

Di bawah kepemimpian Tolchah Mansoer, Pimpinan Pusat IPNU periode awal, segera melakukan konsolidasi visi dan melaksanakan kerja-kerja organisasi sebagaimana diamanatkan dalam Konferensi Lima Daerah di Surakarta. Kegiatan organisasi pada masa awal ini lebih banyak ditujukan untuk melakukan sosialisasi, konsolidasi dan pengembangan IPNU. Yang disosialisasikan adalah visi IPNU yang sejalan dengan NU dalam mengusung Ideologi ahlussunnah wal jama'ah. $^{14}$ Konsistensi Tolchah pada visinya untuk menyatukan pelajar umum dan santri menjadikan organisasi IPNU menyedot perhatian banyak orang. ${ }^{15}$

Kedua, visi IPNU tidaklah dibentuk secara sembarangan melainkan dirumuskan dengan pertimbangan yang matang. Hal itu ditegaskan oleh Tolchah Masoer sebagai pendiri sekaligus pemimpin IPNU 1954 menegaskan tentang tujuan berdirinya

\footnotetext{
13 Ibid., 69.

14 Ibid., 67.

15 Ibid., 70.
} 
IPNU yaitu: “....Berdirinja organisasi Ikatan Pelajar Nadhatul 'Ulama' tidak hanya sekedar mengumpulkan kawan baik dari pesantren, dari diskusi-diskusi menengah Nadhatul 'Ulama' dan umum ataupun dari universitet2. Bukan hanja itu. Ada dasar jang bersifat ideologich jang menyebabkan dia tumbuh. Dia mempunjai sebab dan memiliki pricipe ideologisch jang memerlukan ideologiese dranger jang melaksankannja walau bagaimana djuga zaman dan orang berkata tentangnya."16

Ketiga, Visi IPNU spesifiknya yang dirumuskan tahun 1954 merupakan visi yang dianggap paling sesuai dengan filosofis lahirnya organisasi IPNU dan tidak hanya bersifat formalistik. Oleh karena itu, ketika pada tahun 1988 terjadi perubahan visi dari visi IPNU 1954, mengakibatkan kemunduran pada organisasi IPNU. Perubahan itu khususnya terkait dengan visi kepelajaran diganti dengan kepemudaan. Adanya perubahan visi pada tahun 1988 didasari oleh adanya tuntutan eksternal yaitu Undang-Undang Nomor 8 Tahun 1985 tentang Aturan Keormasan Indonesia yaitu menjadikan OSIS sebagai satu-satunya organisasi pelajar. Perubahan visi IPNU ternyata membawa kegelisahan bagi anggota IPNU. Anggota berpandangan bahwa perubahan visi tersebut bertentangan dengan spirit visi awal IPNU yang dirumuskan dengan pertimbanganpertimbangan sesuai kondisi lahirnya organisasi IPNU dan bukan hanya karena paksaan lingkungan eksternal. Misalnya, terkait dengan perubahan kependekan " $P$ " dan visi pelajar maka berubah pula sasaran

16 Ibid., 59.

${ }^{17}$ Muhammad Rifda Ujza, Panduan Materi MAKESTA $P C$ IPNU IPPNU Kab. Pekalongan, (Pekalongan: 2014), 16-17. mad'uw IPNU, yang awalnya adalah pelajar (yang bersekolah di sekolah umum dan juga pelajar pesantren-pesantren), berubah menjadi membina remaja secara umum. Padahal pemilihan pelajar dalam visi memiliki pertimbangan kondisi tertentu yang diperhitungkan oleh organisasi pada masa awal berdiri. Perubahan visi IPNU mengakibatkan kemunduran IPNU pada tahun-tahun tersebut. Organisasi seperti kehilangan ruh perjuangan pendirinya dan anggota juga kehilangan jati dirinya sebagai kader. ${ }^{17}$ Oleh karena itu, pada kongres IPNU ke-13 dilakukan usaha mengembalikan visi agar sesuai dengan khitah. Pada kongres tersebut diputuskan bahwa mengembalikan IPNU pada garis perjuangan yang semestinya yaitu berdasarkan pada visi IPNU yang dirumuskan pada tahun 1954. Hasil kongres ini ditegaskan kembali pada kongres IPNU ke 14 di Surabaya.

Berangkat dari fenomena kemenarikan visi IPNU tahun 1954, tulisan ini ingin menjawab persoalan bagaimana proses dan pertimbangan perumusan visi IPNU pada tahun 1954 dengan menggunakan studi pustaka/literatur. Harapannya, tulisan ini dapat mengembangkan kajian keorganisasian pada organisasi dakwah, sehingga organisasi dakwah dapat semakin profesional.

Penelusuran terhadap studi terdahulu yang mengkaji masalah perumusan visi dalam organisasi Islam/nonprofit, di antaranya adalah: (1) "Pernyataan Visi dan Misi Perguruan Tinggi" dalam Jurnal Mimbar. ${ }^{18}$

\footnotetext{
18 Hamdan, “Pernyataan Visi.," 90-103.
} 
Studi ini bertujuan menjelaskan pertimbangan-pertimbangan yang seharusnya diperhatikan dalam merumuskan visi misi yang baik pada organisasi nonprofit berbentuk perguruan tinggi. Dalam menjelaskan pertimbanganpertimbangan perumusan visi menggunakan tinjauan literatur yang bersifat teoritis. (2) "Urgensi Perumusan Visi, Misi, dan Nilai-Nilai pada Lembaga Pendidikan Islam" dalam Jurnal Tarbawi Vol. 01 No.01 2016. ${ }^{19}$ Studi ini menyimpulkan bahwa dalam perjalanan sejarahnya, peran atau fungsi lembaga pendidikan Islam tersebut tidak akan terwujud tanpa dibarengi dengan perumusan visi, misi, dan nilai pendidikan Islam itu sendiri. Sebab dengan visi, misi dan nilai maka arah pendidikan Islam itu nantinya menjadi lebih jelas dan terukur. Pernyataan visi, misi dan nilai suatu organisasi dilakukan untuk membantu organisasi dalam pemilihan prioritasprioritas lembaga. Dalam menjelaskan urgensi visi misi pada lembaga pendidikan Islam, tulisan ini menggunakan literatur yang bersifat teoritis. (3) "Merumuskan Visi Misi Lembaga Pendidikan dalam Jurnal IImiah Saintikom". ${ }^{20}$ Studi ini menyimpulkan bahwa perumusan visi dalam lembaga pendidikan bukan hal yang mudah, dalam merumuskannya perlu melibatkan para stakeholder agar semua keinginan tercakup di dalamnya. Selain itu visi perlu dirumuskan mencakup tujuan yang besar sampai dengan hal kecil-kecil yang urgen, seperti: anggaran tahunan sehingga tergambar identitas organisasi, dalam tataran praktis

19 Pramitha Devi, “Urgensi Perumusan Visi, Misi, Dan Nilai-nilai Pada Lembaga Pendidikan Islam," Jurnal Tarbawi Vol. 01 No.01 (2016), 1-9.

${ }^{20}$ Ahmad Calam dkk., "Merumuskan Visi dan Misi Lembaga Pendidikan", Jurnal IImiah Saintikom Vol.15, No. 1, Januari, (2016), 53-68. perumusan visi juga dibutuhkan supervisi, dalam mewujudkan sekolah yang memiliki kualitas baik perlu direncanakan dan dilakukan rekayasa. Studi ini juga menggunakan studi pustaka yang bersifat teoritis dalam menggagas prinsip-prinsip perumusan visi dalam lembaga pendidikan.

Secara keseluruhan studi-studi terdahulu tentang perumusan visi pada organisasi nonprofit atau Islam, banyak berfokus pada objek material pada organisasi nonprofit yang berbentuk perguruan tinggi atau lembaga pendidikan Islam. Sedangkan, penelitian pada organisasi dakwah belum ditemukan. Tulisan ini ingin mengisi tema penelitian visi yang selama ini belum ada yaitu dalam konteks pertimbangan dan langkah-langkah perumusan visi pada sebuah organisasi nonprofit berbentuk organisasi dakwah. Selain itu, studi terdahulu lebih berfokus memaparkan atau menggagas urgensitas dan pertimbangan perumusan visi dalam lembaga pendidikan dengan menggunakan literatur teori-teori terkait. Sedangkan dalam tulisan ini lebih menekankan pada langkah-langkah dan pertimbangan perumusan visi yang dipraktikan oleh organisasi IPNU pada tahun 1954.

Sementara studi terkait dengan organisasi IPNU telah banyak dilakukan, di antaranya: (1) Skripsi berjudul: Profil Organisasi Pemuda Berbasis Keagamaan (Studi Kasus PAC IPNU-IPPNU Kecamatan Mranggren Kebupaten Demak) karya Hartini. ${ }^{21}$ (2) Skripsi berjudul Pendidikan Karakter

21 Hartini, "Profil Organisasi Pemuda Berbasis Keagamaan (Studi Kasus PAC IPNU-IPPNU Kecamatan Mranggren Kebupaten Demak)," (Skripsi: Universitas Negeri Walisongo, Semarang), 2015. 
Kepemimpinan Remaja dalam Organisasi IPNU-IPPNU (Ikatan Pelajar Nahdlatul Ulama- Ikatan Pelajar Putri Nahdlatul Ulama) Pimpinan Anak Cabang Padamara Kab. Purbalingga karya Rouf Muta'ali. ${ }^{22}$ (3) Skripsi berjudul Peran ketua IPPNU PAC Juwiring dalam Meningkatkan Pendidikan Agama Islam bagi Remaja di Kecamatan Juwiring (tahun periode 2014 / 2016) karya Siti Fatimah. ${ }^{23}$ (4) Skripsi berjudul Peran Ikatan Pelajar Nadhatul Ulama-Ikatan Pelajar Putri Nadhatul Ulama Dalam Pemberdayaan Pemuda Melalui Pendidikan di Desa Adiwerna Tegal karya Ahmad Afandi. ${ }^{24}$ Dari studi-stusi terdahulu tentang IPNU, belum ditemukan kajian terhadap permasalahan perumusan visi IPNU.

Tulisan ini termasuk jenis studi deskriptif kualitatif, studi pustaka dengan menggunakan metode dokumen, yaitu metode yang menggali data atau catatan peristiwa yang sudah berlalu secara sistematis dan objektif, baik dalam bentuk tulisan atau dokumen. ${ }^{25}$ Metode pengumpulan data dilakukan dengan studi pustaka melalui membaca secara cermat terhadap literatur-literatur yang digunakan. ${ }^{26}$ Sumber-sumber kepustakaan dipilah sesuai dengan rumusan masalah yang diteliti. ${ }^{27}$ Literatur dan dokumen yang digunakan antara lain: (1) K.H. Moh. Tolchah

22 Rouf Muta'ali, “Pendidikan Karakter Kepemimpinan Remaja dalam Organisasi IPNUIPPNU (Ikatan Pelajar Nahdlatul Ulama- Ikatan Pelajar Putri Nahdlatul Ulama) Pimpinan Anak Cabang Padamara Kab. Purbalingga," (Skripsi: IAIN Purwokerto, Purwokerto), 2017.

${ }^{23}$ Siti Fatimah, "Peran Ketua IPPNU PAC Juwiring dalam Meningkatkan Pendidikan Agama Islam bagi Remaja di Kecamatan Juwiring (Tahun Periode 20142016)," (Skripsi: IAIN Surakarta, Surakarta), 2017.

${ }^{24}$ Ahmad Afandi, "Peran Ikatan Pelajar Nadhatul Ulama-Ikatan Pelajar Putri Nadhatul Ulama Dalam Pemberdayaan Pemuda Melalui Pendidikan di Desa
Mansoer Biografi Profesor NU yang terlupakan karya Caswiyono Rusydie Cakrawangsa dkk; (2) Lajur-lajur Pemikiran Islam Peta Pergulatan Intelektual Indonesia karya Tiar Anwar; (3) Sejarah IPNU dalam website http://.www.ipnu.or.id, (4) Buku Panduan Mu'tamar Pertama IPNU tanggal 28 Februari s/d Maret 1955 di Malang; (5) Panduan Materi MAKESTA PC IPNU IPPNU Kabupaten Pekalongan karya Muhammad Rifda Ujza; (6) Kehidupan Ringkas 29 Tokoh NU karya Abdlul Halim Hasan, dkk; (7) Naskah Hasil Kongres XVIII IPNU Boyolali Jawa Tengah 04-08 Desember 2015 (Prinsip Perjuangan Ikatan Pelajar Nahdlatul Ulama) dalam website http://www.ipnu.or.id (8) Tentang NU dalam website http://.www.nu.or.id.

Teknik analisis data berdasarkan Miles dan Hubberman terdiri dari: (1) reduksi data; (2) data display; dan (3) conclusion drawing/verification. $^{28}$ Reduksi data dilakukan dengan memilih beberapa data yang dibutuhkan, serta membuang datadata yang tidak terkait dengan rumusan masalah. Penyajian data dilakukan dalam bentuk narasi singkat disertai dengan kutipan data pendukungnya. Sedangkan penarikan kesimpulan dilakukan dengan mengidentifikasi pola-pola, proposisiproposisi terkait dengan alur proses

Adiwerna Tegal," (Skripsi: UIN Syarif Hidayatullah, Jakarta), 2017.

25 Sugiyono, Metode Penelitian Manajemen Pendekatan Kuantitatif, Kualitatif, Kombinasi, Penelitian Tindakan, Penelitian Evaluasi, (Bandung: Alfabeta, 2015), 396.

26 Mestika Zed, Metode Penelitian Kepustakaan (Jakarta: Yayasan Obor, 2004), 31.

${ }^{27}$ Asep Saeful Muhtadi \& Agus Ahmad Safei, Metode Penelitian Dakwah (Bandung: Pustaka Setia, 2003), 180.

28 Mattew B. Miles dan A. Michael Huberman, Analisis Data Kualitatif, diterjemahkan Tjejep Rohendi Rohidi (Jakarta: UI Press, 1992), 15-16. 
perumusan visi dan pertimbanganpertimbangan dalam perumusan visi.

\section{Perumusan Visi Organisasi}

\section{Pengertian Visi Organisasi}

Ada berbagai definisi tentang visi antara lain: (1) tujuan ideal; (2) cetak biru organisasi di masa depan; (3) gambaran tentang hal-hal yang perlu dicapai bersifat jangka panjang, berorientasi masa depan tujuan dan memiliki daya tarik emosional yang tertanam dalam serangkaian nilai yang mengarah pada perubahan dan menggambarkan masa depan yang kredibel, realistis, menarik, menginspirasi, dan lebih baik daripada status quo; (4) sebuah agenda (harapan) yang menjadi pertimbangan anggota untuk diikuti. ${ }^{29}$

Visi menurut A.B. Susanto adalah sebuah gambaran mengenai tujuan dan cita-cita di masa depan yang harus dimiliki organisasi sebelum disusun rencana bagaimana mencapainya. ${ }^{30}$ Visi bukan hanya sekedar mimpi atau keinginan, melainkan tujuan bersama organisasi yang dinyatakan dengan kata-kata yang singkat, jelas, kompetitif, dan menggugah perasaan. Selain itu, visi tak dapat dilepaskan dari pemimpin organisasi sebagai penggagas visi. Fred R. David, menjelaskan bahwa visi menjawab pertanyaan mendasar tentang "ingin jadi seperti apa kita?"31 Visi harus mampu menjawab keinginan organisasi di masa depan, ingin jadi seperti apa organisasi tersebut, atau singkatnya ingin

\footnotetext{
${ }^{29}$ O'Connell, et.al, “Organizational Visioning.," 105.

30 A.B. Susanto Visi \& Misi. (Jakarta : The Jakarta Consulting Group,tt.), 15.

31 Fred R. David, Manajemen Strategis (Jakarta: Salemba Empat: 2006), 16.
}

memecahkan masalah apa organisasi tersebut ke depannya. ${ }^{32}$

Definisi yang digunakan dalam tulisan ini, bahwa visi adalah suatu pernyataan komprehensif tentang segala sesuatu yang diharapkan organisasi pada masa yang akan datang dan dibuat sebagai pedoman atau arah jangka panjang organisasi. Visi berupa gambaran ideal tentang cita-cita (keinginan) dari organisasi di masa depan yang dirumuskan dengan singkat, jelas, biasanya dinyatakan dengan kata-kata yang kompetitif dan menggugah perasaan. Serta didalamnya menggambarkan keyakinan dan nilai pendiri (pemimpin) terhadap kondisikondisi ideal yang harus diwujudkan di masa mendatang. Visi menjadi daya tarik anggota untuk bergabung dengan organisasi, sebab di dalamnya menawarkan filosofis (alasan) lahirnya organisasi dan cita-cita organisasi. Komponen dalam visi adalah: (1) sesuatu gambaran ideal masa depan yang itu sifatnya masih abstrak umum; (2) menggambarkan filosofis/alasan lahirnya organisasi; (3) bersifat jangka panjang. Ada pula yang menambahkan bahwa dalam visi harus terdapat fokus geografis (regional, nasional, atau internasional) dan menunjukan keunggulan atau fokus bisnis. ${ }^{33}$

\section{Nilai Penting Visi Organisasi}

Visi merupakan unsur penting dalam organisasi sebagai bagian dari perencanaan strategis. Visi keberadaannya penting karena mengungkapkan atau menyatakan untuk alasan apa organisasi itu ada, dan ke

\footnotetext{
${ }^{32}$ Sooksan Kantabutra, "Toward a behavioral theory of vision in organizational settings," Leadership \& Organization Development Journal, Vol. 30 No. 4, (2009), 321.

33 O'Connell, et.al, "Organizational Visioning.," 115.
} 
mana organisasi itu akan berkembang. Dengan adanya visi akan mendorong para stakeholder memiliki langkah yang terpadu untuk mencapai tujuan. Perlunya visi tidak dibatasi oleh ukuran maupun domain pengabdiannya. Bukan hanya organisasi berskala besar, organisasi kecil pun memerlukan visi. Bukan sekedar organisasi profit, organisasi nonprofit juga memerlukan visi. ${ }^{34}$ Bagi pihak ekternal, dengan adanya visi dapat memberikan dukungan dan pertisipasi untuk kemajuan lembaga tersebut. ${ }^{35}$

Dari penelitian yang dilakukan Dave J. O'Connell dkk, menyatakan bahwa visi sangat memengaruhi hasil kerja organisasi, melalui berbagai mekanisme, baik secara tunggal maupun bersama-sama dengan faktor lain. Visi berdampak pada kinerja organisasi, efektivitas kelompok, pertumbuhan perusahaan dan dapat membangun hubungan baik dengan staf maupun kepuasan pelanggan. ${ }^{36} \mathrm{Di}$ sisi lain, ketiadaan visi dalam sebuah organisasi akan membawa perpecahan. Sebab, tanpa visi akan sangat memungkinkan organisasi berfokus pada tujuan jangka pendek dan melakukan kecerobohan di masa depan, serta tak jarang organisasi terfokus pada individu dan departemen jangka pendek yang bersifat egoisme sektoral sehingga memunculkan internal war. $^{37}$

\footnotetext{
34 Hamdan, "Pernyataan Visi.," 102.

35 Hamdaini, "Fungsi Visi Dan Misi Dalam Perencanaan Pendidikan," Jurnal Darussalam, Volume 8, No.1, Januari - Juni (2009), 37.

${ }^{36}$ Ibid., 103-104.
}

\section{Langkah-langkah Perumusan Visi Organisasi}

Kuncoro menegaskan bahwa dalam visi setidaknya terdiri dari dua komponen antara lain: (1) ideologi inti, Ideologi inti menunjukan karakter abadi dari sebuah organisasi dan identitas yang penting bagi organisasi. Nilai inti merupakan prinsip atau ajaran organisasi; (2) gambaran masa depan, gambaran masa depan visi setidaknya memiliki ciri: (a) berorientasi ke depan, artinya memberikan gambaran yang menyeluruh tentang apa yang diinginkan oleh daerah, (b) inspiratif, artinya mendorong semua orang menuju imajinasi atau impian yang disepakati, (c) realistis, artinya berupaya menggambarkan realitas yang paling optimal selama kurun waktu tertentu. ${ }^{38}$

Sedangkan langkah-langkah perumusan visi menurut Kuncoro antara lain: (1) mengaudit nilai/ideologi inti organisasi, visi perlu dibangun dari nilai inti yang diharapkan organisasi; (2) mengelaborasi tujuan organisasi, tujuan dapat berorientasi pada laba atau tidak, besar atau kecil, lokal atau global, perusahaan harus memiliki tujuan akan keberadaannya; (3) memasukan gambaran singkat tentang apa yang dilakukan oleh organisasi tersebut untuk mencapai tujuannya; (4) merumuskan sasaran umum. Sasaran adalah target semua organisasi bekerja sama untuk mewujudkannya. Sasaran juga menyatukan

\footnotetext{
${ }^{37}$ Nada K. Kakabadse et al, "Visioning- the pathway : A process model," European Management Journal, Vol. 23(2), (2005), 14.

38 Adi Nugroho Dewanto, "Perbedaan Corporate Visioning Antara Perusahaan Kecil dan Menengah Di Kota Surakarta," (Skripsi: Universitas Atmajaya, Yogyakarta, 2010), 15.
} 
semua anggota organisasi dan unit subbisnisnya mencapai tujuan akhir. ${ }^{39}$

Sedangkan Susanto menyarankan beberapa langkah dalam merumuskan atau mengembangkan visi organisasi, ${ }^{40}$ antara lain: (1) auditing the organization (mengetahui kondisi organisasi secara Objektif yaitu sumber daya organisasi diantaranya: sumber daya manusia, dana, waktu, dan sarana yang dimiliki); (2) flaturing enviroment (melakukan pemetaan lingkungan seperti pesaing organisasi lain, lalu masalah penting yang mendasari lahirnya organisasi seperti kemanusiaan, ilmu dan teknologi, ekonomi, politik, seni budaya, dan etika, serta kondisi pasar (konsumen); (3) auditing the vision (mengaudit visi yang lama atau yang pernah ada sebelumnya; (4) mapping the domain (melakukan pemetaan keunikan atau keunggulan kompetitif organisasi, bisa nama atau kelebihan lainnya yang dimiliki oleh organisasi. Selain itu juga dapat dirumuskan secara umum hendak ke manakah bisnis [organisasi]? Serta sebenarnya dimana posisi saat ini?); (5) developing alternatif vision (membuat alternatif visi dalam kata lainya disini adalah penggagas membuat beberapa alternetif gambaran impian di masa depan. Dalam membuat alternatif visi juga dapat melalui melibatkan anggota organisasi yang lain melalui proses sharring terhadap mimpimimpi yang dimiliki anggota organisasi); (6) chosing the right vision (memutuskan visi apa yang akan digunakan untuk memecahkan masalah tersebut). (7) packaging the new vision (melakukan pengemasan visi atau dalam kata lainnya adalah meredaksionalkan [membuat]

\footnotetext{
39 Ibid., 16.

${ }^{40}$ Susanto, Visi \& Misi., 43.
}

pernyataan visi barunya yang itu mampu memcahkan masalah yang ada. Pernyataan visi ini hendaknya dirumuskan dalam kalimat yang singkat, padat, jelas dan menggugah perasaan).

\section{Faktor-Faktor Pertimbangan Perumusan Visi}

Dalam perumusan visi, terdapat beberapa faktor pertimbangan yang memungkinkan diperhatikan oleh organisasi dalam merumuskan visi, antara lain: pertama, pendiri/pemimpin organisasi. Zaccaro dan Banks menelusuri dua perspektif lahirnya visi, yaitu ada yang menekankan pada keutamaan nilai-nilai pribadi para eksekutif yang memengaruhi visi dan yang lainnya menekankan proses negosiasi di antara para pemangku kepentingan menciptakan gambaran bersama tentang masa depan. Beberapa penulis kemudian menawarkan sintesis pandangan, menunjuk pada peran individu visioner dalam mengonstruksi visi dan didasarkan dalam nilai-nilai yang ingin mereka sebarkan. ${ }^{41}$ Zaccaro and Banks menekankan pentingnya nilai-nilai pribadi eksekutif dalam membentuk citra organisasi di masa depan. Visi awal terkadang mencerminkan nilai-nilai pribadi pemimpin muncul dengan cara menentang sebuah kondisi yang tidak ideal dengan penjelasan yang logis. Secara umum, penciptaan visi dipicu ketika ada ketegangan yang dirasakan antara apa yang ada di organisasi saat ini dan apa yang mungkin terjadi di masa depan. ${ }^{42}$ Dalam sebuah penelitian eksperimental, para peneliti menunjukkan bahwa pembentukan visi melibatkan pengalaman pribadi dari seorang pemimpin.

\footnotetext{
41 O'Connell, et.al, "Organizational Visioning.," 106.

42 Ibid., 107.
} 
Kedua, lingkungan eksternal. Pada sisi lainnya, lahirnya visi ada yang dirumuskan berangkat dari tuntutan kekuatan institusional (lingkungan eksternal) yang menuntut penciptaan pernyataan visi untuk dianggap sebagai peserta yang sah di bidang tertentu atau diakui secara keorganisasiannya. Hal itu biasanya terjadi dalam lembaga nonprofit, ketika para pemimpin dituntut untuk membuat visi formal agar mendapatkan pendanaan dari lembaga di luar organisasi atau mendapat pengakuan dari lembaga akreditasi eksternal. Visi yang hanya berangkat dari tuntutan kekuatan eksternal biasanya tidak mengarah pada perubahan yang nyata dan tidak efektif memengaruhi kinerja organisasi. ${ }^{43}$

Ketiga, kondisi organisasi. Visi dapat dibentuk mempertimbangkan jenis/karakteristik organisasi ataupun letak geografis organisasi. Lahirnya visi juga dapat berangkat dari adanya masalah terkait dengan kinerja masa depan perusahaan (sejenis gangguan signifikan) atau ketika sebuah organisasi berusaha untuk bangkit dari kemunduran atau kesulitan yang parah. Visi juga dapat berangkat dari harapan organisasi untuk melakukan transformasi untuk menjadi organisasi yang lebih besar. ${ }^{44}$ Bolman dan Deal mengusulkan bahwa empat frame tersebut memengaruhi caracara di mana individu menganalisis situasi organisasi dan mengambil tindakan, yaitu: (a) aspek sumber daya manusia (SDM) yang menekankan keterlibatan manusia dalam

${ }^{43}$ Ibid.

${ }^{44}$ Ibid., 108.

45 Bolman, L. G., and Deal, T. E. "Leadership and Management Effectiveness: A Multi-Frame, MultiSector Analysis," Human Resource Management, Volume 30, Isue 4, (1991), 509-534. tempat kerja; (b) kerangka politik yang menarik perhatian pada dinamika persaingan dan konflik atas sumber daya yang langka, kerangka struktural yang menunjuk pada peran, hubungan otoritas dan tujuan; (c) dan kerangka simbolik yang menyoroti budaya dan makna organisasi. ${ }^{45}$ Hal-hal tersebut akan memengaruhi konten dari visi. Dalam jenis kategori organisasi tertentu (misalnya: tipe industri/organisasi, ukuran), isi visi akan bervariasi menurut kerangka kognitif yang dominan.

\section{Kronologis Perumusan Visi IPNU Tahun 1954}

\section{Permasalahan Yang Mendasari Lahirnya} Visi

Organisasi IPNU lahir dari kegelisahan Tolchah Mansoer terhadap kondisi pelajar nahdhliyin. Tolchah Mansoer sangat kental dengan nilai-nilai NU, militansinya terhadap NU telah terbentuk sejak kecil, khususnya tradisi pondok pesantren (pernah mondok di Pesantren Tebu Ireng \& Pesantren Lasem), ${ }^{46}$ dan figur pada beberapa kyai besar organisasi NU. Selain itu, Tolchah Mansoer juga memiliki semangat intelektual yang diperoleh dari sekolah umum yaitu taman siswa, universitas gajah mada. ${ }^{47}$ Tolchah Mansoer gemar mengikuti organisasi dan menjabat berbagai jabatan penting dalam organisasi keislaman, khususnya yang berkarakter NU (seperti: Ikatan Moerid Nadhlatoel Oelama, Barisan Sabillilah dan Markas Oelama Djawa Timur). ${ }^{48}$

\footnotetext{
${ }^{46}$ Abdlul Halim Hasan, dkk., Kehidupan Ringkas 29 Tokoh NU, (Jakarta: Yayasan Saifudin Zuhri 2012), 435.

${ }^{47}$ Cakrawangsa dkk., K.H. Moh. Tolchah., 53.

48 Ibid., 49.
} 
Kegelisahannya mulai muncul saat remaja (SMA), ketika ia melihat bahwa organisasiorganisasi pelajar yang berbasis NU saat itu masih bersifat kedaerahan (misalnya: Tsamrotul Mustafidzin hanya berfokus di Surabaya, Persatoen Siswa Anak-Anak NO dan Persatoen Anak Moerid NO yang ada di Malang, dan masih banyak lagi organisasi yang bersifat kedaerahan). Di sisi lain, organisasi yang bersifat nasional hanya ada dua yaitu PII (yang merepresentasikan pelajar Islam) dan HMI (yang merepresentasikan mahasiswa). Saat itu di organisasi NU, kegiatan pemuda atau pelajar masih bersifat kedaeraan, padahal di luar komunitas NU pada masa proklamasi mulai tumbuh organisasi-organisasi pelajar dan mahasiswa yang bersifat nasional seperti: Perkumpulan Pemuda Kristen (PPKI), Gerakan Mahasiswa Nasionalis Indonesia (GMNI), Himpunan Mahasiswa Islam (HMI, Gerakan Mahasiswa Sosialis (Germasos) dan Pelajar Islam Indonesia. Organisasi-organisasi tersebut memiliki perbedaan ideologi masing-masing dan umumnya berafilisasi pada kekuatan politik tertentu. Dalam konstelasi gerakan muda di atas, melalui Kongres Al-Islam pada 1949, PII dinobatkan satu-satunya organisasi pelajar muslim dan HMI sebagai satusatunya organisasi mahasiswa muslim. ${ }^{49} \mathrm{Hal}$ ini pada akhirnya memaksa Tolchah Mansoer termasuk juga kalangan tradisionalis yang lain saat itu untuk masuk PII dan HMI. PII dan HMI dijadikan wadah dan aktualisasi gerakan bagi mahasiswa Islam, baik dari kalangan tradisionalis maupun modernis.
Kegelisahannya semakin mencuat, ketika melihat permasalahan di pelajar nahdliyin terkait keikutsertaan mereka pada organisasi PII dan HMI. Terlebih saat itu kontestasi politik para "orang tuanya" yang berafiliasi di NU dan Partai Masyumi (seiring keluarnya NU dari organisasi Masyumi). Para orang tua pelajar nadhliyin tidak setuju dengan keanggotaan anak-anaknya dalam organisasi HMI dan PII. Saat itu kontestasi antara golongan modernis dan tradisionalis sudah merambah ke kalangan pelajar. Kala itu NU yang berada dalam konstelasi politik tanah air yang penuh pertarungan. Pada era itu 1954 Indonesia dilanda instabilitas politik. Kondisi yang disebabkan pertarungan ideologi antar kekuatan partai politik. Perpecahan antar organisasi kepemudaan pun menguat, misalnya: HMI berafiliasi ke Masyumi, GMNI ke PNI, Germasos ke PSI. ${ }^{50}$ Oleh karena itu, semakin menguat kegelisahan Tolchah Mansoer terhadap perselisihan dan permasalahan di masyarakat Islam yang diakibatkan tidak adanya wadah bagi pelajar NU yang sesuai dengan ideologi kalangan tradisionalis. ${ }^{51}$ Wadah tersebut dibutuhkan dalam rangka kaderisasi maupun lahan aktualisasi gerakan bagi pelajar nadhliyin. Tolchah Mansoer pernah menulis: "....haruslah diinsjafi berdirinja organisasi Ikatan Peladjar Nadhatul 'Ulama' bukan sekedar tumbuh dan ditumbuhkan begitu sadja, apalagi kalau diingat suasana ketika awal kali dilahirkan organisasi ini dilahirkan di persada tanah air. Sungguh waktu itu merupakan saat jang pahit, jang terdapat di dalamnja pertentangan dan perselisihan jang dirasakan tidak enak oleh masjarakat kita terutama masjrakat Islam."

51 Ibid., 53.

49 lbid., $48-52$.

50 lbid., 66. 
Dari data di atas menunjukan bahwa pada tahap awal sebelum melahirkan visi dari organisasi IPNU, ada proses pencetusan masalah yang diawali dari kegelisahan terhadap kondisi masyarakat Islam saat itu, khususnya kalangan pelajar NU. Persoalan yang menjadi kegelisahan antara lain: fenomena pengorganisasian pelajar NU yang hanya bersifat kedaerahan, adanya persoalan kegelisahan pelajar NU untuk bergabung dengan organisasi yang bukan NU melainkan justru bersifat modern (PII dan $\mathrm{HMI}$ ), serta kebutuhan kaderisasi untuk mempertahankan nilai-nilai NU di antara berbagai ideologi yang lain.

Kegelisahan atas kondisi pelajar nadhliyin yang tidak terakomodasi di organisasi PII maupun HMI ini ternyata bukan hanya dirasakan Tolchah Mansoer melainkan juga dirasakan oleh aktivis mahasiswa NU yang lain. Misalnya, Ismail Makky pernah mengakui bahwa saat itu muncul kegelisahan terhadap PII. Kegelisihan ini terjadi karena organisasi pelajar itu tidak mengakomodasi pelajar-pelajar dari pesantren sehingga para santri NU tidak ada yang mengurus. Kegelisahan inilah yang mendorong aktivis mahasiswa berharap dapat mendirikan suatu organisasi yang bisa mencakup antara pelajar pesantren dan pelajar umum. ${ }^{52} \mathrm{Hal}$ tersebut sebagaimana ditulis Bachtiar, "Pada perkembangannya dominasi kelompok Modernis di HMI dan PII membuat mereka merasa tidak mendapatkan tempat. Situasi itu diperburuk dengan keluarnya NU dari Masyumi. Karena alasan itu pada tanggal 2 Februari 1954 sebagian pelajar dan mahasiswa dari keluarga muslim tradisionalis mendirikan

52 lbid.

53 Tiar Anwar Bachtiar, Lajur-Lajur Pemikiran Islam Peta Pergulatan Intelektual Indonesia, (Garut: ttt). ikatan pelajar Nahdlatul Ulama (IPNU) sebagian besar pendirinya pernah di HMI seperti Tolchah Mansoer, Ismail Makky, dan Nuril Huda. ${ }^{153}$

Dari data di atas menunjukan bahwa kegelisahan itu bukan hanya dialami oleh penggagas saja melainkan juga beberapa aktivis mahasiswa lainnya. Kegelisahan itu terkait dengan tidak ditampungnya inspirasi kalangan pelajar/mahasiswa NU dalam organisasi seperti PII.

\section{Membuat Gagasan Cita-Cita} Membentuk Organisasi Pelajar NU yang bersifat Nasional

Tolchah Mansoer kemudian mendiskusikan kegelisahannya dengan aktivis mahasiswa NU lainya. Dari diskusi-diskusi tersebut, mulai terbangunlah cita-cita atau visi dalam benak Tolchah Mansoer untuk menggabungkan dua elemen pelajar NU yang mencakup pelajar pesantren (santri) maupun yang bersekolah di sekolah umum yang memiliki nilai-nilai NU. Sebab, untuk merealisasikan ajaran agama sangat dibutuhkan baik pengetahuan yang bersifat umum maupun agama. Dalam sejarah IPNU ditulis, "Cita-cita Tholhah Mansoer ingin mempersatukan pelajar dan santri dalam wadah IPNU. .... Tolchah Mansoer memiliki keinginan untuk menjembatani kesenjangan pengetahuan antara pelajar dan mahasiswa di lembaga pendidikan umum dan pelajar di pondok pesantren". ${ }^{54}$

Sedangkan dalam buku Panduan Materi Makesta ditulis, "Pada dasarnya Ikatan Pelajar Nahdlatul Ulama (IPNU) didirikan sebagai organisasi kesiswaan dan

54 "Sejarah IPNU," Situs Ipnu.or.id, diakses 20 januari 2018, http://.www.ipnu.or.id 
kesantrian, ia dimasukkan dalam rangka menyatukan gerakan langkah dan dinamisasi kaum terpelajar di kalangan Nahdliyyin."55 Dalam Buku Panduan Muktamar Pertama IPNU, Tolchah Mansoer pernah menulis bahwa masuknya pelajarpelajar NU pada berbagai macam organisasi di luar NU membawa pengalaman sekaligus kerugian. Yang mana, untung saja muncul kesadaran untuk insyaf dan ingin menghidupkan gerakan sendiri yang mengeratkan hubungan antar pelajar NU baik golongan santri maupun pelajar nahdhliyin yang bersekolah di sekolah umum, melalui organisasi IPNU. ${ }^{56}$

Gagasan tentang mendirikan organisasi pelajar NU secara nasional, semakin mengkristal ketika menemukan gagasan yang sama dari diskusi dengan kalangan aktivis mahasiswa NU di Yogyakarta yang saat itu yang memaparkan kegelisahan mereka terhadap bentuk organisasi pelajar NU yang selama ini bersifat kedaerahan. Oleh karena itu muncul gagasan dibenak Tolchah Mansoer dan beberapa pendiri yang lain, yaitu M. Shufyan Cholil (Yogyakarta), H. Musthafa (Solo) dan Abdul Ghony Farida (Semarang) untuk melakukan pengorganisasian pelajar NU yang bersifat nasional. Tolchah Mansoer dan temantemannya sangat aktif mengonsolidasikan gerakan kaum muda NU. Mereka sering berkumpul di daerah Bunijo Yogjakarta (kawasan sebelah barat perempatan Tugu). Di sebuah rumah kos-kosan di daerah tersebut, gerakan kaum muda itu dirumuskan. ${ }^{57}$ Dalam Sejarah IPNU ditulis,

\footnotetext{
55 Ujza, Panduan Materi MAKESTA., 16.

56 Buku Panduan Mu'tamar Pertama IPNU Tgl. 28 Februari S/D Maret 1955 di Malang, (Lakpesdam), 7. 57 Cakrawangsa dkk., K.H. Moh. Tolchah Mansoer., 54.
}

"Munculnya organisasi IPNU bermula dari adanya jam'iyah yang bersifat lokal atau kedaerahan. Wadah tersebut berupa kumpulan pelajar dan pesantren yang dikelola dan diasuh para ulama. Jamiyah atau perkumpulan tersebut tumbuh di berbagai daerah hampir di seluruh Wilayah Indonesia, misalnya jam'iyah diba'iyah. Jam'iyah tersebut tumbuh dan berkembang banyak dan tidak memiliki jalur tertentu untuk saling berhubungan. $\mathrm{Hal}$ ini disebabkan karena perbedaan nama yang terjadi di daerah masing-masing, mengingat lahir dan adanya-pun atas inisiatif atau gagasan sendiri-sendiri antar para pendiri. ${ }^{158}$

Selain gagasan tentang organisasi pelajar yang bersifat nasional. Tolchah juga memiliki gagasan visi untuk membuat organisasi pelajar yang berfungsi sebagai wadah kaderisasi, aktualisasi dan menjaga internalisasi nilai-nilai NU atau ahlussunnah wal jama'ah. Tolchah Mansoer menyatakan: "Indonesia mayoritas penduduknya adalah beragama Islam dan berhaluan Ahlussunnah Wal Jama'ah sehingga untuk melestarikan faham tersebut diperlukan kader-kader penerus yang nantinya mampu mengkoordinir, mengamalkan dan mempertahankan faham tersebut dalam kehidupan bermasyarakat, berbangsa dan bernegara serta beragama. ${ }^{159}$

Cakrawangsa, dkk. Dalam bukunya menyebutkan, "Tolchah berpandangan bahwa NU harus memiliki organisasi

\footnotetext{
58 "Sejarah IPNU," Situs Ipnu.or.id, diakses 20 januari 2018, http://.www.ipnu.or.id 59 Ibid.
} 
kepelajaran, sehingga kader-kader NU (putra-putra orang NU yang kuliah di Yogyakarta saat itu) tidak lagi bergabung dengan PII dan HMI karena ideologi kedua organisasi dianggap berbeda dari NU."60

Dari data-data di atas menunjukan bahwa dalam perumusan visi organisasi IPNU tahun 1954 setidaknya ada beberapa gagasan penting sebagai cita-cita yang ingin diwujudkan oleh organisasi, antara lain: (1) gagasan tentang menyatukan antara pelajar dari golongan santri dan sekolah umum; (2) keinginan mempertahankan nilai-nilai ahlussunnah wal jama'ah dengan adanya organisasi yang bersifat nasional bukan hanya lokal; (3) cita-cita membentuk kader NU yang sesuai dengan kebutuhan organisasi NU.

\section{Usaha Mengonsolidasikan Visi Organisasi}

Adanya gagasan atau cita-cita ingin menyatukan antara pelajar dari golongan santri dan sekolah umum secara nasional berdasarkan dengan nilai-nilai ahlussunnah wal jama'ah semakin menguat karena adanya simbolisasi tokoh Tolchah Mansoer yang dipandang memiliki karakter yang sesuai dengan visi tersebut. Cakrawangsa, dkk. dalam bukunya menyebutkan, bahwa cita-cita penggabungan dua dunia (pelajar santri dan umum) itu mulai terbangun dibenak Tolchah Mansoer dan la sangat aktif dalam mengonsolidasikan gerakan kaum muda NU. Ismail Makky menyatakan: "Tolchah Mansoer saat itu sangat merepresentasikan dua dunia pelajar, sebab saat itu Tolchah merupakan satu dari sedikit kalangan santri tradisionalis kala itu

${ }^{60}$ Cakrawangsa dkk., K.H. Moh. Tolchah Mansoer., 57. yang juga mengenyam pendidikan umum. Sehingga, pemikiran Tolchah muda kala itu sangat merefleksikan pemikiran dan persoalan antara pesantren dan pendidikan umum. "61Moensif Nahrawi (mantan Sekretaris Jenderal PP IPNU pada masa Tolchah Mansoer menyatakan: "Tolchah merupakan orang yang sejak awal memiliki kegelisahan yang sama tentang generasi muda. Tolchah memiliki pandangan bahwa NU harus memiliki organisiasi kepelajaran sehingga kader-kader NU (putra-putra orang NU yang kuliah di Yogjakarta saat itu) tidak lagi bergabung dengan PII dan HMI. ${ }^{62}$

\section{Usaha Pembentukan Organisasi Untuk Dapat Memformalisasi Visi}

Langkah berikutnya yang ditempuh untuk dapat memformalisasi visi/tujuan organisasi adalah melakukan pembentukan organisasi terlebih dahulu. Titik-titik kesamaan gagasan visi ini mendorong para pelopor pendiri organisasi (yang nantinya bernama IPNU) untuk menyatukan seluruh gagasan perkumpulan tersebut ke dalam satu wadah resmi di bawah payung Nahdlatul Ulama. Gagasan ini disampaikan dalam Konferensi Besar LP Ma'arif NU pada bulan Februari 1954 di Semarang oleh pelajar-pelajar dari Yogyakarta, Surakarta, dan Semarang, yaitu M. Shufyan Kholil, A. Mustahal, Ahmad Masyhud, dan Abdul Ghoni Farida. Gagasan pendirian organisasi IPNU tidak dapat dilepaskan dari landasan historis lahirnya organisasi antara lain: pertama, aspek ideologis, yang menegaskan posisi Indonesia sebagai negara yang mayoritas penduduknya beragama Islam dan berhaluan ahlussunnah wal jama'ah sehingga perlu dipersiapkan

\footnotetext{
${ }^{61}$ Cakrawangsa dkk., K.H. Moh. Tolchah Mansoer., 53-54.

62 Ibid., 56-57.
} 
kader-kader penerus perjuangan NU dalam kehidupan beragama, berbangsa dan bernegara. Kedua, aspek pedagogis, yaitu adanya cita-cita (keinginan) untuk menjembatani kesenjangan antara pelajar dan santri serta mahasiswa pada pendidikan umum dan pendidikan pondok pesantren, sekaligus ingin memberdayakan potensi mereka untuk meningkatkan kualitas sumberdaya manusia, utamanya bagi generasi pelajar NU. Ketiga, aspek sosiologis, yaitu adanya persamaan tujuan (visi), kesadaran dan keikhlasan akan pentingnya suatu wadah pembinaan bagi generasi penerus para ulama dan penerus perjuangan bangsa. ${ }^{63}$

Gagasan untuk menyatukan cita-cita dan nama perkumpulan (organisasi) yang diusulkan dalam Konferensi Besar LP Ma'arif NU diterima oleh anggota konferensi dengan suara bulat dan mufakat. Sehingga, dilahirkan suatu organisasi yang bernama IPNU (Ikatan Pelajar Nahdlatul Ulama) dengan ketua pertama M. Tolchah Mansoer. ${ }^{64}$ Sedangkan yang ditetapkan sebagai pendiri organisasi antara lain: Tolchah Mansoer, Ismail Makky (Mahasiswa IAIN Kalijogo), Mahbub Junaidi (Mahasiswa UI), M. Sofyan Kholil, A. Ghani Farida, M. Uda, M. Sahal Makmun (Mahasiswa UI), Abdurrohman Wahid (Jawa Timur), Ilyas Ru'at (Jawa Barat). ${ }^{65}$

\section{Peresmian/Formalisasi Visi Organisasi IPNU 1954}

Selanjutnya diadakan konferensi segi lima di Solo pada 30 April - 1 Mei 1954. Pertemuan

63 Naskah Hasil Kongres XVIII IPNU Boyolali Jawa Tengah 04 - 08 Desember 2015 (Prinsip Perjuangan Ikatan Pelajar Nadhatul Ulama). Diakses tanggal 20 April 2018. http://www.ipnu.or.id/wpcontent/uploads/2016/05/BUKU-HASIL-KONGRESBAGIAN-II.pdf itu melibatkan perwakilan pendiri IPNU dari Yogyakarta, Semarang, Solo, Jombang dan Kediri. Dalam konferensi segi lima ini dirumuskanlah secara formal asas organisasi, yaitu ahlussunnah wal jama'ah, tujuan organisasi yaitu mengemban risalah Islamiyah, mendorong kualitas pendidikan dan mengkonsolidir pelajar NU secara nasional. ${ }^{66}$ Tujuan berdirinya organisasi IPNU juga ditegaskan sebagai organisasi kader, bukan didorong oleh semangat berpolitik. Hal itu ditegaskan oleh Tolchah Mansoer: "Mungkin orang menganggap kita ini berpolitik. Tetapi orang tidak tahu bagian apa dari Nadhatul 'Ulama' itu yang berpolitik. Dalam hal ini perlulah dimengerti bahwa hubungan IPNU adalah dengan Ma'arif (bagian pengajaran) dan IPNU tidak akan berbicara dalam hal politik."

Organisasi IPNU memang dibentuk dalam konteks menyiapkan kader NU. Namun, di tengah situasi pertarungan politik menjelang pemilu 1955, tentunya menjadi organisasi yang bertujuan murni kaderisas bukanlah hal yang mudah. Untuk itu dikeluarkan, Pengurus Pusat (PP) IPNU yang menegaskan bahwa IPNU berfokus pada kaderisasi. Didorong adanya kebutuhan kaderisasi baik untuk menunjang kebutuhan organisasi IPNU di bidang sosial kemasyarakatan, partai politik ataupun semua bidang. Terkait dengan kebutuhan kader-kader di bidang politik, hal itu dijelaskan oleh M. Said Bairy (selaku salah satu kader perintis IPNU), "Pada tahun 1954, NU baru berusia 2 tahun menjadi partai politik. Dibutuhkan kader-kader. Di

64 "Sejarah IPNU," Situs Ipnu.or.id, diakses 20 januari 2018, http://.www.ipnu.or.id

65 Ujza, Panduan Materi MAKESTA., 16-17.

66 Cakrawangsa dkk., K.H. Moh. Tolchah Mansoer., 55 
mana pun partai politik adalah sebuah sarana untuk bisa ikut berkuasa dalam peyelenggaraan pemerintahan negara yang baik." ${ }^{\prime 67}$

Dari pemaparan di atas, terlihat bahwa dalam proses peresmiaan visi/tujuan organisasi IPNU secara umum terdapat komponen: asas ahlussunnah wal jama'ah, berfokus pada kualitas pendidikan, kaderisasi dan mengonsolidasi pelajar NU secara nasional. Kaderisasi yang dilakukan bukan hanya menyiapkan kualitas kader di bidang sosial kemasyarakatan, namun juga berbagai bidang lain termasuk politik.

\section{Perumusan Redaksi Visi IPNU 1954}

Gagasan tentang tujuan dan asas organisasi tersebut pada akhirnya diwujudkan dalam sebuah redaksi visi yang secara formal menjadi visi organisasi IPNU. Jika merujuk pada redaksi visi formal IPNU yaitu: "Terwujudnya pelajar-pelajar bangsa yang bertaqwa kepada Allah Swt., berakhlakul karimah, menguasai ilmu pengetahuan dan teknologi, memiliki kesadaran dan tanggung jawab terhadap terwujudnya tatanan masyarakat yang berkeadilan dan demokratis atas dasar ajaran Islam ahlussunah wal jama'ah." Maka dapat terlihat bahwa redaksi visi mengandung komponen-komponen utama gagasan citacita organisasi, yaitu terkait dengan fokus organisasi pada pelajar (baik dari basis sekolah maupun pondok pesantren), asasnya adalah ahlussunah wal jama'ah, dan arahnya adalah kaderisasi yaitu pembentukan kesadaran dan tanggung jawab terhadap berbagai sektor masyarakat.
Redaksi visi itu merupakan pemadatan terhadap cita-cita yang ingin diwujudkan sesuai dengan latar belakang historis lahirnya organisasi IPNU. Dari teks yang dipilih setidaknya IPNU ingin menegaskan perbedaan visinya dibandingkan organisasi HMI dan PII dengan menunjukan secara tegas asas organisasinya adalah ahlussunah wal jama'ah. Hal ini juga mempertegas bahwa cita-cita organisasi IPNU sejalan dengan organisasi induknya yaitu Nahdlatul Ulama.

\section{Analisis Langkah-Langkah Perumusan Visi Organisasi IPNU Tahun 1954}

1. Perumusan Masalah Perlunya Visi Organisasi IPNU 1954

Visi IPNU 1954 dirumuskan berangkat dari analisis kondisi lingkungan eksternal, khususnya terkait dengan permasalahan yang ada di masyarakat Islam. Dari proses ini tercetuslah masalah yang dipandang penting untuk dipecahkan oleh penggagas visi organisasi. Ruang lingkup permasalahan yang mendasari lahirnya visi, bisa spesifik pada segmen tertentu ataupun masyarakat secara luas dalam berbagai sektor masyarakat. Jika merujuk pada organisasi IPNU sebagai organisasi dakwah maka permasalahan awal yang mendasari visi adalah berkaitan dengan persoalan umat Islam, khususnya permasalahan pada pelajar dan organisasi NU sebagai organisasi induk.

Persoalan yang mendasari visi organisasi, muncul dari adanya kesenjangan antara nilai-nilai ideal/ideologi yang dimiliki oleh penggagas organisasi dengan realitas aktual

67 lbid., 58-59. 
yang ada di masyarakat saat itu. Sebagaimana yang terjadi pada penggagas visi yaitu Tolchah Mansoer, kegelisahan pada permasalahan pelajar dan NU, tidak dapat dilepaskan dari nilai-nilai kecintaan Tolchah Mansoer pada NU yang terinternalisasi sejak kecil dan pengalamannya berorganisasi yang banyak terkait dengan dunia pelajar atau kepemudaan. Sehingga, meskipun di masyarakat banyak persoalan di berbagai sektor kehidupan, belum tentu semuanya menarik bagi penggagas visi untuk dipecahkan. Sebab, pendiri/penggagas visi memiliki nilai-nilai ideal yang akan memengaruhi bidang permasalahan masyarakat yang menarik dan penting dipilih untuk dipecahkan.

Dalam proses awal ini, penggagas visi IPNU bukan hanya mengidentifikasi persoalanpersoalan apa saja yang ada di masyarakat Islam, namun juga melakukan analisis terhadap dampak kemudhorotan jika permasalahan itu tidak dipecahkan. Semakin besar dampak kemudhorotannya maka mendorong kegelisahan yang semakin kuat bagi penggagas visi untuk memecahkan persoalan tersebut. Sebagaimana yang dilakukan oleh Tolchah Mansoer dalam merumuskan permasalahan yang mendasari lahirnya visi. Awalnya Tolchah Mansoer mengamati persoalan-persoalan yang ada di masyarakat Islam, khususnya saat dia bergabung dengan organisasi kepemudaan yang tidak berideologikan ahlussunnah wal jama'ah dan mengamati persoalan yang ada di organisasi NU (terkait dengan tidak adanya organisasi yang bersifat nasional). Permasalahan itu tidak hanya diamati secara sekilas, namun juga difikirkan secara mendalam dengan melihat dampak yang ditimbulkan, seperti: dampak tidak adanya organisasi kepemudaan NU yang bersifat nasional terhadap berjalannya kaderisasi NU, konflik antara orang tua dan anak karena keikutsertaan dalam organisasi yang berbeda nilai dengan NU, maupun terhadap aktusnya inspirasi dari golongan pelajar NU. Dari penghayatan terhadap dampakdampak dari permasalahan masyarakat Islam, melahirkan kegelisahan yang kuat bagi penggagas visi (Tolchah Mansoer) untuk memecahkan masalah tersebut. Dalam konteks organisasi nirlaba, spesifiknya dakwah proses merumuskan masalah masyarakat yang mendasari lahirnya visi merupakan tahapan yang penting. Sebab, organisasi dakwah lahir dalam rangka memecahkan persoalan yang ada di masyarakat, khususnya masyarakat Islam.

\section{Tahap Perumusan, Cara Analisis dan Karakteristik Gagasan Visi IPNU 1954.}

Setelah menghayati kegelisahan dari permasalahan yang ada di masyarakat maka tahapan berikutnya penggagas visi (Tolchah Mansoer) berupaya untuk membuat pemecahan dari permasalahan tersebut. Pemecahan masalah atas kegelisahan inilah yang disebut dengan gagasan visi atau citacita organisasi. Gagasan visi yang ingin diwujudkan oleh organisasi IPNU 1954, antara lain: (1) gagasan tentang menyatukan antara pelajar dari golongan santri dan sekolah umum; (2) keinginan mempertahankan nilai-nilai ahlussunnah wal jama'ah dengan adanya organisasi yang bersifat nasional bukan hanya lokal (kedaerahan); (3) cita-cita membentuk kader NU yang sesuai dengan kebutuhan organisasi IPNU. Cita-cita IPNU salah satunya adalah membentuk kader yang dapat memajukan organisasi NU di berbagai 
bidang, bukan hanya dalam hal dakwah. Mengingat saat itu, organisasi NU berkiprah juga bukan hanya dalam bidang dakwah keagamaan, melainkan berbagai sektor sosial kemasyarakatan, termasuk politik. Dalam situasi yang demikian, pemudapemuda NU harapannya memiliki militansi secara ideologi, pengetahuan dan kemamampuan yang dapat memenuhi berbagai bidang organisasi NU.

Dalam merumuskan gagasan visi tersebut, penggagas visi IPNU melakukan diskusi dengan beberapa aktivis mahasiswa lainnya, yang memiliki nilai-nilai sejalan dengan Tolchah Mansoer yaitu nilai NU serta memiliki pemahaman terhadap persoalan organisasi kepemudaan dan NU. Dalam merumuskan pemecahan masalah, para pendiri IPNU juga melihat berbagai peluang yang ada dilingkungan (masyarakat Islam) maupun organisasi NU untuk memecahkan persoalan yang digelisahkan selama ini. Misalnya: potensi pemudapemuda NU, ada yang berasal dari golongan santri dan pelajar sekolah umum, yang mana masing-masing memiliki potensi untuk dapat saling melengkapi secara pengetahuan dan dapat berkerjasama dalam satu semangat nilai NU yaitu ahlussunnah wal jama'ah. Selain itu, pendiri juga melihat bahwa potensi untuk membentuk organisasi pelajar NU sangat besar sebab selama ini telah ada organisasi kepemudaan yang tersebar di berbagai daerah dengan nama yang berbeda-beda namun secara nilai-nilai adalah ahlussunnah wal jama'ah, dan berbagai peluang lainnya.

Jika dilihat dari gagasan visi organisasi IPNU, maka secara umum gagasan visi memiliki karakteristik: (a) bersifat cita-cita ideal yang menjadi keinginan diwujudkan di masa depan; (b) menjawab persoalan yang ada di masyarakat; (c) memiliki kerealistisan untuk diwujudkan, sebab juga berbasis pada analisis peluang-peluang yang ada di masyarakat dan organisasi NU saat itu.

\section{Tahap Konsolidasi Gagasan Visi Organisasi}

Dalam perumusan visi IPNU, gagasan citacita IPNU tidak hanya menjadi gagasan yang semu, sebab ada tokoh (Tolchah Mansoer) yang gigih mengonsolidasikan gagasan visi. Adanya upaya mengonsolidasikan visi secara gigih dan konsisten tersebut dapat membangun keyakinan anggota bahwa visi realistis. Diskusi konsolidasi gagasan visi dilakukan Tolchah Mansoer bersama M. Shufyan Cholil (Yogyakarta, H, Musthafa (Solo) dan Abdul Ghony Farida (Semarang). Hal ini mendorong pendiri-pendiri yang lain memiliki semangat untuk dapat memformalkan visi dalam sebuah wadah organisasi.

Dalam konteks organisasi IPNU, tokoh Tolchah Mansoer dipandang oleh pendiri yang selainnya sebagai penganggas visi sekaligus mencerminkan karakter gagasan visi organisasi IPNU. Tolchah Mansoer memiliki pengalaman sebagai pemuda NU yang mengenyam pendidikan di sekolah umum dan pesantren. Selain itu, Tolchah Mansoer juga aktif diberbagai organisasi kepemudaan. Tolchah Mansoer juga secara aktif mengonsolidasikan kegelisahannya terhadap kondisi masyarakat dan mendiskusikan gagasan cita-cita organisasi (visi) yang harus diperjuangkan secara ideologis. Hal ini membuat para pendiripendiri organisasi lainnya menjadi yakin dan sepakat bahwa gagasan visi tersebut dapat diwujudkan. 


\section{Tahap Pembentukan Organisasi untuk Memformalisasikan Gagasan Visi.}

Dalam konteks organisasi IPNU, sebelum organisasi IPNU berdiri, proses perumusan visi sudah berjalan. Namun, perumusan visi tersebut masih berupa gagasan visi yang belum formal. Untuk dapat memformalkan visi dan kedepannya dapat mewujudkan visi tersebut maka diperlukan langkah membentuk organisasi. Terlebih dalam konteks IPNU, visi organisasi IPNU tidak dapat dilepaskan dari spirit organisasi induknya yaitu NU (Nahdlatul Ulama). Sehingga, untuk memformalkan visi organisasi, maka perlu dibuat organisasi yang disahkan oleh organisasi induknya melalui Kongres Besar Ma'arif NU. Dengan diresmikannya organisasi IPNU, maka selanjutnya IPNU bisa membuat visi organisasi IPNU secara formal dan perangkat organisasi yang lainnya. Selain mengesahkan berdirinya organisasi IPNU 1954, kongres juga mengesahkan ketua umum pertama organisasi IPNU yaitu Tolchah Mansoer. Keputusan penunjukan Tolchah Mansoer ini karena dirinya dipandang tokoh pelajar yang memiliki gagasan awal dan pemikiran untuk menggabungkan kaum santri dan pelajar umum. Selain itu, pada peresmian ini, juga diputuskan beberapa orang yang dipandang ikut dalam menggagas berdirinya organisasi yaitu: Tolchah Mansoer, Ismail Makky (Mahasiswa IAIN Kalijogo), Mahbub Junaidi (Mahasiswa UI), M. Sofyan Kholil, A. Ghani Farida, M. Uda, M. Sahal Makmun (Mahasiswa UI), Abdurrohman Wahid (Jawa Timur), llyas Ru'at (Jawa Barat).

Pada tahap ini dapat diketahui bahwa ada perbedaan antara langkah-langkah yang dilakukan oleh organisasi dakwah dan organisasi bisnis. Dalam organisasi bisnis biasanya visi dibentuk ketika sudah ada perusahaannya, sehingga visi lahir dari kecendrungan melihat persoalan apa yang ada di internal perusahaannya. Namun, dalam konteks dakwah justru organisasi terbentuk setelah adanya kegelisahan terhadap permasalahan di masyarakat dan gagasan visi organisasi. Dalam konteks organisasi dakwah, visi merupakan sesuatu yang harus dirumuskan atau digagas terlebih dahulu sebelum membentuk organisasi. Meskipun pada fase sebelum organisasi terbentuk, tidak sampai pada redaksi/pernyataan visi formal, melainkan masih kegelisahan-kegelisahan dan gagasan cita-cita yang hendak diwujudkan oleh penggagas visi. Perumusan kegelisahan dan gagasan visi butuh dilakukan terlebih dahulu agar organisasi memiliki arah yang jelas tujuan dibentuknya dan tidak hanya membuat visi untuk tujuan formalitas semata. Baru setelah kegelisahan itu benarbenar penting dan gagasan visi jelas, langkah penting selanjutnya adalah membentuk organisasi dan memformalkan visi.

Pembentukan organisasi adalah bagian penting dalam proses perumusan visi secara formal. Sebab, apabila tidak ada wadah organisasi, maka segala gagasan visi tidak akan pernah terwujud. Sebaliknya, dengan adanya sebuah organisasi, akan melahirkan kekuatan untuk memperjuangkan visi. Dengan adanya organisasi yang memiliki visi yang jelas akan mampu menghimpun banyak anggota yang memiliki kecintaan yang sama untuk memperjuangkan visi. Hal itu pula yang terjadi dalam organisasi IPNU 1954. Visi IPNU yang awalnya hanya gagasan sekelompok aktivis mahasiswa NU yang memiliki cita-cita terkait dengan pelajar dan NU, pada akhirnya dapat 
berkembang lebih luas ke berbagai pelosok tanah air, terutama kota-kota yang ada pesantrennya. Dengan adanya organisasi IPNU dan konsolidasi ke berbagai daerah, maka bermunculanlah berbagai cabang IPNU di daerah. ${ }^{68}$

\section{Tahap Peresmian Visi Organisasi IPNU.}

Setelah organisasi terbentuk dan memiliki struktur, maka langkah berikutnya adalah peresmian atau formalisasi visi. Pada tahap ini pada dasarnya tidak banyak proses dialektika atau perdebatan terkait gagasan terhadap visi. Sebab, di tahap-tahap sebelumnya sudah ada kesepemahaman terhadap kondisi persoalan yang ingin dipecahkan, nilai-nilai yang diperjuangan termasuk gambaran ideal cita-cita yang ingin diwujudkan. Sehingga, pada tahap ini adalah pengesahan visi secara formal oleh struktur yang berwenang dalam organisasi. Peresmian visi IPNU secara formal dilakukan pada Konferensi Segi Lima di Solo pada 30 April-1 Mei 1954. Pertemuan ini melibatkan perwakilan dari Yogyakarta, Semarang, Solo, Jombang dan Kediri. Konferensi tersebut adalah konsolidasi organisasi pertama kali setelah resmi berdiri. Konferensi ini berhasil merumuskan komponen-komponen visi, seperti asas visi organisasi yaitu ahlussunnah wal jama'ah, tujuan organisasi yakni mengemban risalah Islamiyah, mendorong kualitas pendidikan, dan mengonsolidasi pelajar.

Peresmian visi secara formal oleh struktur yang sah dalam organisasi merupakan bagian penting dalam perumusan visi. Sebab, jika visi/tujuan organisasi tidak disahkan melalui mekanisme yang berlaku dalam organisasi, maka tidak akan tercipta kesepakatan dan kesatuan arah cita-cita yang hendak diperjuangkan oleh organisasi. Tanpa adanya kesepakatan formal, sangat memungkinkan pula visi dapat digeser oleh pihak-pihak yang tidak memahami gagasan awal visi yang ingin diwujudkan oleh para pendiri organisasi. Sehingga, untuk menjamin eksistensi organisasi dalam jangka waktu yang panjang dan tetap mengarah pada visi yang diperjuangkan, maka visi organisasi perlu disahkan oleh struktur yang berwenang dalam organisasi.

\section{Tahap Perumusan Redaksi Visi.}

Gagasan organisasi yang masih prinsipprinsip dalam organisasi IPNU 1954 dijadikan sebuah teks dalam bahasa yang singkat, padat, jelas menggambarkan citacita organisasi dan dapat menginspirasi anggota. Begitupula yang dilakukan oleh organisasi IPNU, gagasan awal tentang asas dan tujuan organisasi dibuat dalam bentuk kalimat-kalimat dalam satu paragraf untuk menggambarkan secara tegas visi organisasi IPNU 1954. Redaksi visi organisasi IPNU yaitu "Terwujudnya pelajar-pelajar bangsa yang bertaqwa kepada Allah SWT, berakhlakul karimah, menguasai ilmu pengetahuan dan teknologi, memiliki kesadaran dan tanggung jawab terhadap terwujudnya tatanan masyarakat yang berkeadilan dan demokratis atas dasar ajaran Islam ahlussunah wal jama'ah."

Tahap perumusan redaksi visi, merupakan bagian yang penting juga untuk dilakukan dalam perumusan visi. Sayangnya studi ini tidak mendapati data secara eksplisit tentang proses dan pertimbanganpertimbangan detil yang digunakan oleh organisasi IPNU dalam meredaksikan visi.

68 Cakrawangsa dkk., K.H. Moh. Tolchah Mansoer., 60-61. 
Namun, jika melihat pada redaksi visinya, terlihat bahwa visi organisasi IPNU menggambarkan cita-cita organisasinya, khususnya yang berangkat dari permasalahan pada lingkup pelajar-pelajar NU dan terkait dengan nilai ideologi ahlussunah wal jama'ah. Paham ahlussunah wal jama'ah juga tercantum dalam tujuan organisasi Nahdlatul Ulama yaitu "Menegakan ajaran Islam menurut paham ahlussunah wal jama'ah di tengah-tengah kehidupan masyarakat, di dalam wadah Negara Kesatuan Republik Indonesia (NKRI). ${ }^{69}$

Selain itu, pernyataan visi IPNU nampaknya memiliki keterkaitan dengan bidang garap organisasi IPNU (sebagaimana yang disahkan oleh organisasi NU melalui Konferensi Ma'arif), yaitu sebagai organisasi di bawah NU yang bergerak di bidang pengkaderan pelajar. Sehingga, fokusnya adalah mencetak pelajar-pelajar yang sesuai dengan karakteristik dan kebutuhan organisasi Nahdlatul Ulama yaitu bertaqwa kepada Allah, berakhlakul karimah, menguasai ilmu pengetahuan dan teknologi, memiliki kesadaran dan tanggung jawab terhadap terwujudnya tatanan masyarakat yang berkeadilan dan demokratis atas dasar ajaran Islam ahlussunah wal jama'ah.

\section{Faktor-Faktor Pertimbangan Lahirnya Visi IPNU Tahun 1954}

Jika dilihat dari proses perumusannya maka setidaknya ada beberapa faktor utama yang

\footnotetext{
69 “Tentang NU," Situs nu.or.id., diakses 14 Mei 2018. http://.www.nu.or.id
}

mendasari lahirnya visi organisasi IPNU antara lain:

\section{Pendiri (Pemimpin) yang Visioner}

Dalam organisasi IPNU faktor pengalaman dan nilai-nilai pendiri sangat mewarnai gagasan visi yang hendak dirumuskan. Sebagaimana yang ada di data, bahwa lahirnya visi IPNU tidak dapat dilepaskan dari sosok pendirinya yaitu Tolchah Mansoer. Tolchah Mansoer melakukan penentangan terhadap kondisi yang ada di masyarakat Islam saat itu, yang dipandang tidak sesuai dengan nilai-nilainya selama ini. Tolchah Mansoer mengalami kegelisahan pada kondisi masyarakat Islam saat itu (1954), spesifiknya tentang persoalan pelajar, fenomena organisasi kepemudaan dan pengorganisasian organisasi Nahdlatul Ulama. Hal itu tidak dapat dilepaskan dari nilai-nilai kecintaan pada ideologi ahlussunnah wal jamaa'ah pada Nahdlatul Ulama, yang terinternalisasi sejak kecil dan pengalamannya berorganisasi yang banyak terkait dengan dunia pelajar atau kepemudaan. Kegelisahan ini melahirkan semangat untuk menentang kondisi yang tidak ideal tersebut, untuk dapat dirubah menjadi lebih baik sesuai dengan nilai-nilai ideal yang dijunjung oleh pendiri selama ini.

Ikatan pengalaman rasa yang kuat antara penggagas visi dan permasalahan masyarakat, dapat menghasilkan idealisme yang kuat dalam memecahkan permasalah di masyarakat tersebut. Terlebih dalam konteks organisasi dakwah seperti NU yang memiliki banyak tantangan, kepentingan dan tidak berorientasi pada materi. Tanpa adanya ikatan pengalaman rasa yang kuat antara pemimpin (pendiri visi organisasi dakwah) dengan persoalan masyarakat 
yang hendak dipecahkan visi maka visi hanya akan menjadi teks belaka dan tidak akan mampu membesarkan sebuah organisasi. Sehingga, dalam konteks organisasi IPNU 1954, perumusan visi IPNU sangat dipengaruhi oleh faktor pendiri organisasi sebagai penggagas visi dan pemimpin pertama organisasi IPNU.

\section{Lingkungan Eksternal}

Lahirnya visi organisasi IPNU sangat terkait dengan kondisi masyarakat saat itu yang sedang mengalami persoalan akibat tidak adanya wadah yang menampung pelajar NU. Serta adanya pertentangan ideologi yang kuat di masyarakat, antara kalangan modernis dan tradisi maupun antara Islam dengan ideologi-ideologi yang lain, khususnya dikalangan pemuda. Selain itu, visi IPNU mengandung semangat mempertegas perbedaan antara organisasi IPNU dan organisasi Islam lainnya (PII dan HMI). Hal itu didasari oleh ketidakpuasan pada organisasi kepemudaan tersebut karena tidak menganut nilai ahlussunah wal jama'ah, cenderung modern dan tidak dapat menampung inspirasi kaum muda/pelajar NU.

Kekuatan eksternal yang mendorong lahirnya visi IPNU bukan hanya tuntutan kekuatan institusional (lingkungan eksternal), yang menuntut penciptaan pernyataan visi untuk dianggap sebagai peserta yang sah di bidang tertentu atau diakui secara keorganisasiannya. Sebab, lahirnya visi IPNU berangkat dari kegelisahan dan kesadaran pendiri untuk memecahkan persoalan yang ada di masyarakat tersebut. Implikasinya, visi IPNU bukan hanya sekedar menjadi pajangan dan formalitas, melainkan terus disosialisasikan dan diperjuangan oleh organisasi IPNU hingga saat ini. Selain itu, adanya visi yang sesuai dengan salah satu persoalan di masyarakat dan memiliki keunggulan kompetitif dari organsasi lainnya, sehingga dapat menjadi daya tarik tersendiri bagi orang lain untuk bergabung. Hal tersebut dalam organisasi IPNU mampu melahirkan keberhasilan pembukaan cabang-cabang IPNU di berbagai wilayah.

\section{Kondisi Organisasi}

IPNU merupakan organisasi yang lahir karena kecintaan pendiri terhadap nilai-nilai organisasi Nahdlatul Ulama (ahlussunah wal jama'ah), sehingga lahirnya tidak dapat dilepaskan dari kegelisahan yang terjadi dalam organisasi induknya yaitu NU. Oleh karena itu, kondisi organisasi NU menjadi perhatian pendiri dalam merumuskan visi, misalnya terkait dengan persoalan pengorganisasian gerakan kaum muda NU yang masih bersifat kedaerahan dan kebutuhan kaderisasi SDM organisasi NU yang dapat memenuhi berbagai sektor kehidupan. Kondisi organisasi yang dipetakan dalam perumusan visi IPNU bukan hanya persoalan-persoalan yang ada di organisasi Nahdlatul Ulama, melainkan juga peluang-peluang yang memungkinkan ada di organisasi Nahdlatul Ulama untuk mewujudkan visi organisasi IPNU. Misalnya: potensi pondok-pondok pesantren yang memiliki nilai-nilai ahlussunnah wal jama'ah, potensi aktivis pemuda NU yang memiliki kesadaran yang sama akan permasalahan di NU, potensi organisasi kepemudaan yang telah terbentuk dan bersifat kedaerahan selama ini, dan lain sebagainya.

Perumusan visi organisasi IPNU bukan berpijak pada kondisi organisasi IPNU sendiri, melainkan justru pada organisasi 
induknya yaitu Nahdlatul Ulama. Hal itu dikarenakan pada saat perumusan visi, organisasi IPNU belum terbentuk. Adanya pengaruh dari kondisi organisasi NU terhadap visi IPNU, akhirnya melahirkan karakter organisasi IPNU yang sejalan dengan organisasi Nahdlatul Ulama. Selain itu dalam pembentukan organisasi IPNU diperlukan pengesahan dari organisasi NU sebab secara karakter visinya sama dengan $\mathrm{NU}$, hanya saja fokus bidang lebih spesifik pada pengkaderan pelajar Nahdlatul Ulama.

\section{Kesimpulan}

Dalam organisasi IPNU perumusan visi melalui enam tahap yaitu: (1) perumusan masalah yang melatarbelakangi lahirnya visi; (2) perumusan gagasan cita-cita organisasi sebagai jawaban atas persoalan yang menggelisahkan pendiri; (3) konsolidasi gagasan visi; (4) pembentukan organisasi untuk dapat memformalkan visi organisasi; (5) peresmian visi organisasi IPNU oleh struktur yang berwenang dalam organisasi; (6) perumusan pernyataan/redaksi visi yang singkat, padat, jelas, kompetitif dan dapat menginspirasi anggota. Dalam perumusan visi organisasi setidaknya organisasi IPNU mempertimbangkan: nilai-nilai pendiri organisasi, lingkungan eksternal (persoalan yang ada di masyarakat Islam dan kondisi organisasi lainnya (HMI dan PII) serta kondisi organisasi induknya (Nahdlatul
Ulama). Dengan adanya pertimbanganpertimbangan ini maka visi yang dibuat akan memiliki kejelasan arah, memotivasi dan kompetitiv dari organisasi yang lain.

Dari studi ini juga ditemukan bahwa ada beberapa langkah yang berbeda antara perumusan visi dalam konteks organisasi dakwah dengan organisasi bisnis (perusahaan). Dalam organisasi dakwah visi berangkat dari permasalahan yang ada di masyarakat Islam dan justru visinya dirumuskan sebelum organisasi terbentuk, sedangkan dalam organisasi bisnis langkahlangkahnya tidak demikian. Hal ini menunjukan bahwa dalam bentuk organisasi yang berbeda memungkinkan melahirkan langkah-langkah perumusan visi yang berbeda.

Dari studi ini, diharapkan dapat menjadi pijakan bagi organisasi dakwah yang hendak merancang visi organisasi, agar visi memiliki kejelasan arah, dapat memotivasi anggota dan kompetitif dari organisasi yang lain. Harapannya dalam perumusan visi tidak hanya sebatas tuntutan formalitas dari institusi kekuatan eksternal, sebab hal itu tidak akan berdampak baik bagi kinerja organisasi. Dengan adanya visi yang dirumuskan dengan langkah-langkah yang baik dan sesuai dengan karakteristik organisasi dakwah, harapannya organisasi dakwah dapat semakin profesional, berkembang dan mampu survive hingga masa mendatang.

\section{Bibliografi}

Affandy, Shofyan. Dakwah Strategik (Sebuah Ancangan Teoritis \& Filosofis). Surabaya: Avvaterra, 2017. 
Afandi, Ahmad. "Peran Ikatan Pelajar Nadhatul Ulama-Ikatan Pelajar Putri Nadhatul Ulama Dalam Pemberdayaan Pemuda Melalui Pendidikan di Desa Adiwerna Tegal." Skripsi. UIN Syarif Hidayatullah, 2017.

Ahmad Calam dan Kurniati. "Merumuskan Visi dan Misi Lembaga Pendidikan," Jurnal IImiah Saintikom Vol.15, No. 1, Januari, (2016).

Bachtiar, Tiar Anwar. Lajur-lajur Pemikiran Islam Peta Pergulatan Intelektual Indonesia. Garut, Ttt.

Buku Panduan Mu'tamar Pertama IPNU Tgl. 28 Februari S/D Maret 1955 di Malang.

Caswiyono Rusydie Cakrawangsa, Zainul Arifin dan Fahsin M. Fa'al. KH. Moh. Tolchah Mansoer Biografi Profesor NU yang terlupakan. Lkis, 2009.

Darbi, William Phanuel Kofi. "Of Mission and Vision Statements and Their Potential Impact on Employee Behaviour and Attitudes: The Case of A Public But Profit-Oriented Tertiary Institution." International Journal of Business and Social Science, Vol. 3 No. 14, Special Issue - July, (2012): 95-109.

David, Fred R. Manajemen Strategis. Jakarta: Salemba Empat, 2006.

David J O'Connell and Arun Pillutla. "Organizational Visioning: An Integrative Review." Group \& Organization Management, Vol. 36(1), (2011): 103-125.

Devi, Pramitha. "Urgensi Perumusan Visi, Misi, Dan Nilai-nilai Pada Lembaga Pendidikan Islam." Jurnal Tarbawi Vol. 01 No.01 (2016): 1-9.

Dewanto, Adi Nugroho. "Perbedaan Corporate Visioning Antara Perusahaan Kecil dan Menengah Di Kota Surakarta." Skripsi: Universitas Atmajaya, Yogyakarta. 2010

Fatimah, Siti. "Peran ketua IPPNU PAC Juwiring dalam Meningkatkan Pendidikan Agama Islam bagi Remaja di Kecamatan Juwiring (Tahun Periode 2014-2016)." Skripsi. IAIN Surakarta. 2017.

Hamdan, Yusuf. :Pernyataan Visi Dan Misi Dalam Perguruan Tinggi.: Mimbar Volume XVII, No. 1 Januari - Maret, (2001): 101-102.

Hamdaini. "Fungsi Visi Dan Misi Dalam Perencanaan Pendidikan," Jurnal Darussalam, Volume 8, No.1, Januari - Juni (2009): 37-46.

Hartini. "Profil Organisasi Pemuda Berbasis Keagamaan (Studi Kasus PAC IPNU-IPPNU Kecamatan Mranggren Kebupaten Demak)." Skripsi. Universitas Negeri Walisongo, 2015.

Hasan, Abdul Halim dkk. Kehidupan Ringkas 29 tokoh NU. Jakarta: Yayasan Saifudin Zuhri, 2012. Kantabutra, Sooksan. "Toward a behavioral theory of vision in organizational settings," Leadership \& Organization Development Journal, Vol. 30 No. 4, (2009).

L.G, Bolman, et al. "Leadership and management effectiveness: A multi-frame, multi-sector Analysis," Human Resource Management, Volume 30, Isue 4, (1991).

Miles dan Huberman. Analisis Data Kualitatif. Diterjemahkan Tjejep Rohendi Rohidi. Jakarta: UI Press, 1992.

Muta'ali, Rouf. "Pendidikan Karakter Kepemimpinan Remaja dalam Organisasi IPNU-IPPNU (Ikatan Pelajar Nahdlatul Ulama- Ikatan Pelajar Putri Nahdlatul Ulama) Pimpinan Anak Cabang Padamara Kab. Purbalingga." Skripsi. IAIN Purwokerto, 2017.

"Naskah Hasil Kongres XVIII IPNU Boyolali Jawa Tengah 04 - 08 Desember 2015 (Prinsip Perjuangan Ikatan Pelajar Nahdlatul Ulama." Diakses tanggal 20 April 2018. 
http://www.ipnu.or.id/wp-content/uploads/2016/05/BUKU-HASIL-KONGRES-BAGIAN-

II.pdf

Mutadi dkk. Metode Penelitian Dakwah. Bandung: Pustaka Setia, 2003.

Nada K. Kakabadse, Andrew Kakabadse, and Linda Lee-Davies. "Visioning the Pathway: A process

Model." European Management Journal, Vol. 23(2), (2005): 237-246.

"Sejarah IPNU," diakses 20 januari 2018, http://.www.ipnu.or.id

Sugiyono. Metode Penelitian Manajemen Pendekatan Kuantitatif, Kualitatif, Kombinasi,

Penelitian Tindakan, Penelitian Evaluasi. Bandung: Alfabeta, 2015.

Sutomo, Soemengen. "Manajemen Strategis Organisasi Nirlaba," Jurnal Kesehatan Masyarakat Nasional Vol.1, No.4, (2007).

Susanto, A.B. Visi \& Misi. (Jakarta: The Jakarta Consulting Group,Ttt.).

Ujza, Muhammad Rifda. Panduan Materi MAKESTA PC IPNU IPPNU Kab. Pekalongan. Pekalongan, 2014.

Wongso, Wawan. “Perumusan Visi, Misi \& Value Statement Serta Standarisasi Proses Bisnis Pada

Perusahaan Berbasis Keluarga". Calyptra: Jurnal IImiah Mahasiswa Universitas Surabaya, Vol.3 No. 1, (2014).

Zed, Mestika. Metode Penelitian Kepustakaan. Jakarta: Yayasan Obor, 2004. 